\title{
The Strategy of Politics in Using Portal Online Media to Implicate a Personalization of Politics that has been done by an Elite Group in North Sulawesi
}

\author{
Rizkya Dwijayanti \\ Department Political Science \\ Airlangga University \\ Surabaya, Indonesia
}

\author{
Stefanus Rodrick Juraman \\ Department Communication Science \\ Airlangga University \\ Surabaya, Indonesia \\ stefanus.rodrick.juraman-2016@fisip.unair.ac.id
}

\author{
Shirley Y. V. I. Goni \\ Sociology Department \\ Sam Ratulangi University \\ Manado, Indonesia
}

\begin{abstract}
The accessibility of online news media today offers a major opportunity for individual's to receive as much information as possible. Thus it becomes the main political news platform for the local people. On the other hand, it creates an opportunity for online media companies to use their influence to promote a particular political agenda and a particular candidate instead of being neutral. Based on the observations, it seems that online news media is being used by political elites to promote oneself and increase their chances of being elected in the various elections. Hence we can find evidence of political elites promoting oneself from the headlines and the contents of the news. This research uses framing analysis methodology. In this case, the news that has been taken from the online media in North Sulawesi will be analyzed using agenda setting theory and the concept of political personalization. As such we can identify individual's political intention's that has been put in the content of the news.
\end{abstract}

Keywords—online media; personalization of politics; political strategy.

\section{INTRODUCTION}

Nowadays, the online media news grows rapidly in Indonesia, especially in the province of North Sulawesi. Based on the data taken from press council, there are twenty six media portal in the cyber net in North Sulawesi. It shows that the people's need in consuming the information through media online news are quite high and online media becomes the main reference of the information for the people there. People think that online media is more effective and efficient in accessibility.

Online media currently is politically influenced by some elite from certain political parties. They use the growth of online media news as the opportunities to increase their popularity and public supports in order to win the election.
Unfortunately, here are some online medias tend to be clearly show their tendency and partiality to the certain politicians. Of course it can change and rid the main function of the media itself. Substantially, Media has to be neutral and independent in delivering the information to the public, so that the information will be factual

This research explores some online medias, they are Manado Post Online, Suluttoday.com from December 2017 until February 2018. This research uses agenda setting theory by Maxwell McComb and Donald Shaw. This theory explains that audiences not only learn about public issues and another matter through the media, they also learn how much importance to attach to an issue or topic from the emphasis the mass media place upon it [1]. Kurt Lang and Gladys Lang said that media tends to be extremely focus on the certain issues. Mass media often tries to create and arrange the political figures to the public. Mass media deliberately and constantly stimulate the people to think, to forget, to analyze the facts around them [2]. Those theories are suitable to analyze the usage of online media as the political strategy that has been done by some political elites in North Sulawesi.

This research is very useful and beneficial to read due to the lack of the review and studies about political tendency in the media online. So that is why we need to understand the political strategy in using the mass media that has been done by the politician to deliver their political propaganda. As we remember that North Sulawesi will have an Election in 2018 and 2019 , so that is why from the beginning of 2017 the politician started to play their role to increase their popularity and gain the public support as much as possible in order to win the election. 


\section{RESEARCH METHOD}

This research uses framing analysis to analyze the political content of the three medias in North Sulawesi, they manadosatunews.com, manadopostonline.com dan suluttoday.com from December 2017 until February 2018. Framing Analysis in the Communication perspective is used to explore the strategy of certain ideology in constructing the facts. This analysis helps us in looking at the strategy of selecting, facts into the news to make it more meaningful, more interesting, or more memorable to lead the audience's interpretation.

Besides that, this analysis can show us the way how the journalists select the issues before finally write the news. This perspective defines which part of the facts will be put and published on the news and the ones that have to be removed [3].

Entman says that Framing is divided into two parts: choice of issues and content of the news. Both of these factors can sharpen the news framing and its content. Abrar explains that there are four framing technique used by the journalist (1) Cognitive dissonance ; (2) Empathy in arranging the personal imagination ;(3) Packing ( the attractiveness impacts on the powerlessness and (4) association (incorporates, actual policy and the focus of the content. At least there are three parts of the news as the object of framing for the journalist, they are the title, the content, and the conclusion of the news [3].

\section{RESUlTS AND DisCUSSION}

Based on the news published on those three online medias got from December 2017 until February 2018, we can know that there are political tendency from certain politicians for their political personalization purposes in using those online medias.

These are the samples of the political tendentious news:

TABLE I.

SAMPLES OF THE POLITICAL TENDENTIOUS NEWS

\begin{tabular}{|c|c|c|c|}
\hline No & Media & Month & News Footage \\
\hline 1 & $\begin{array}{l}\text { Manado } \\
\text { post } \\
\text { Online }\end{array}$ & $\begin{array}{l}10 \text { December } \\
2017\end{array}$ & $\begin{array}{l}\text { Pendukung Ivansa dan CNR } \\
\text { kian Meluas, } \\
\text { MANADO } \\
\text { Partai Golkar harus berhitung } \\
\text { cermat di Pilkada Minahasa. Isu } \\
\text { politik pasangan Ivan Sarundajang } \\
\text { dan Careig N Runtu (Ivansa-CNR) } \\
\text { akan ditinjau kembali merupakan } \\
\text { kerugian. Sebab dukungan } \\
\text { terhadap Ivansa-CNR kian meluas } \\
\text { di seantero Minahasa tanah } \\
\text { tercinta. } \\
\text { The Supporter of Ivansa and } \\
\text { CNR is Increasing a lot } \\
\text { MANADO political party of Golkar } \\
\text { The re-counting their } \\
\text { should } \\
\text { opportunity in winning the election } \\
\text { in Minahasa due to the wrong } \\
\text { choice of the candidate that has } \\
\text { been chosen by them. In this case }\end{array}$ \\
\hline
\end{tabular}

\begin{tabular}{|c|c|c|c|}
\hline No & Media & Month & News Footage \\
\hline & & & $\begin{array}{l}\text { Golkar took the candidate from } \\
\text { PDI party named Ivansa who has } \\
\text { been taken out from PDI party } \\
\text { itself. Even the political issue does } \\
\text { not seem so beneficial for Ivansa, } \\
\text { but he still confidence weather he } \\
\text { will get a lot of supports from } \\
\text { Golkar because Tetty Paruntu as } \\
\text { the head of Golkar Party in North } \\
\text { Sulawesi has decided po put her } \\
\text { legal support for him, as } \\
\text { everybody knows that Tetty } \\
\text { Paruntu is being loved by the } \\
\text { Minahasa People due to her inner } \\
\text { beauty and personality. } \\
\text { Ivansa saat dikonfirmasi mengaku } \\
\text { tidak terganggu wacana kocok } \\
\text { ulang calon Golkar. "Saya tidak } \\
\text { yakin wacana kocok ulang itu, } \\
\text { keluar dari mulut ibu Tetty," } \\
\text { katanya. Sebab Tetty dikenalnya } \\
\text { sosok bersahaja. Kelebihan inilah } \\
\text { yang membuat Tetty begitu dicintai } \\
\text { rakyat dan memimpin Minsel dua } \\
\text { periode. (*) [4] }\end{array}$ \\
\hline 2 & $\begin{array}{l}\text { Manado } \\
\text { post } \\
\text { Online }\end{array}$ & $\begin{array}{l}15 \text { December } \\
2017\end{array}$ & $\begin{array}{l}\text { OLLY Vs. Tetty, Head to Head } \\
\text { Fighting in Governor Election. } \\
\text { PDI Party and Golkar Party seems } \\
\text { to be the most dominant political } \\
\text { parties in North Sulawesi. These } \\
\text { two political parties does not want } \\
\text { to hold some coalitions in winning } \\
\text { the Governor Election because } \\
\text { each of them have the strong } \\
\text { political figure. } \\
\text { Olly Dodokambey is the } \\
\text { incumbent candidate from PDI } \\
\text { party and also known as he head of } \\
\text { its structural political party in } \\
\text { North Sulawesi while Tetty } \\
\text { Paruntu is the mayor of South } \\
\text { Minahasa and also known as the } \\
\text { head of Golkar Party in the } \\
\text { Province of North Sulawesi. } \\
\text { The candidates from PDI party has } \\
\text { failed in some Mayor Election } \\
\text { such us Manado and Sangihe while } \\
\text { Golkar seems to be more } \\
\text { prospectus due to their success in } \\
\text { winning the Mayor Elections. So } \\
\text { that is why the Governor Election } \\
\text { in } 2018 \text { will be a very head to head } \\
\text { competition between those two } \\
\text { political parties and their } \\
\text { candidates. This also will be the } \\
\text { first time for Tetty Paruntu as the } \\
\text { Mayor of South Sulawesi to fight } \\
\text { in Governor Election } \\
\text { Rotion } \\
\text { OLLY - Tetty Adu Kuat } \\
\text { Rivalitas PDI Perjuangan (PDI-P) } \\
\text { dan Partai Golkar (PG) sudah jadi } \\
\text { rahasia umum. Sangat jarang dua } \\
\text { partai besar ini 'rujuk' di pesta } \\
\text { demokrasi. Pilkada serentak } 2015 \\
\text { lalu contohnya. Golkar enggan }\end{array}$ \\
\hline
\end{tabular}




\begin{tabular}{|c|c|c|c|}
\hline No & Media & Month & News Footage \\
\hline & & & $\begin{array}{l}\text { bersanding dengan PDI-P. Bahkan } \\
\text { di Pilkada Minahasa Selatan } \\
\text { (Minsel), Golkar mengusung calon } \\
\text { sendiri, sementara kadernya } \\
\text { Christiany Paruntu dan Franky } \\
\text { Wongkar dicalonkan PDI-P. Di } \\
\text { Pilkada serentak } 2018 \text { mendatang, } \\
\text { diprediksi PDI-P dan Golkar } \\
\text { akan head to head. Ini jadi ajang } \\
\text { pembuktian Olly Dondokambey } \\
\text { sebagai Ketua PDI-P Sulut, yang } \\
\text { pada } 2015 \text { lalu sempat gagal di } \\
\text { Manado dan Sangihe. Di sisi lain, } \\
\text { Pilkada 2018 bagi Christiany } \\
\text { Paruntu atau akrab disapa Tetty } \\
\text { jadi pertarungan pertama setelah } \\
\text { dia resmi jadi Ketua Golkar Sulut. } \\
\text { [5] }\end{array}$ \\
\hline 3 & $\begin{array}{l}\text { Manadon } \\
\text { satuews.c } \\
\text { om }\end{array}$ & $\begin{array}{ll}27 & \text { January } \\
2018 & \end{array}$ & $\begin{array}{l}\text { Stevi Suawaw finally leads the } \\
\text { Hanura Party in the city of } \\
\text { Manado } \\
\text { Stevy Suawa finally lead the } \\
\text { structural organization of Hanura } \\
\text { Party in Manado while her } \\
\text { working partner will be Rusia } \\
\text { Umar as the secretary and Reynold } \\
\text { Wuisan as the treasurer from the } \\
\text { period of } 2015 \text { until 2020. This } \\
\text { political position has been legally } \\
\text { signed by the General Chairman of } \\
\text { Hanura Party In Indonesia Oesman } \\
\text { Sapta Oedang and his General } \\
\text { Secretary Herry Siregar. Based on } \\
\text { the letter of SKEP/418/DPP- } \\
\text { Hanura/I/2018. [6] }\end{array}$ \\
\hline 4 & $\begin{array}{l}\text { Manados } \\
\text { atunews.c } \\
\text { om }\end{array}$ & $\begin{array}{l}17 \text { February } \\
2018\end{array}$ & $\begin{array}{l}\text { PERTA MA DI INDONESIA; } \\
\text { PARTAI HANURA } \\
\text { PERCAYAKAN } \\
\text { PENYANDANG DISABILITAS } \\
\text { PEGANG JABATAN KETUA } \\
\text { PARTAI } \\
\text { Manado (MSN) - Luar biasa, } \\
\text { walau dengan keterbatasan } \\
\text { fisik, Djatris Patiri, SH yang } \\
\text { dikenal sebagai politisi Partai } \\
\text { Hati Nurani Rakyat(Hanura) } \\
\text { begitu memiliki semangat dan } \\
\text { obsesi yang luar biasa untuk } \\
\text { memberi kontribusi Terhadap } \\
\text { masyarakat Djatris yang kini } \\
\text { dipercaya sebagai Ketua Dewan } \\
\text { Pimpinan Cabang (DPC) Partai } \\
\text { Hanura Kabupaten Sangihe } \\
\text { Provinsi Sulawesi Utara (Sulut) ini } \\
\text { menyampaikan targetnya dalam } \\
\text { membesarkan Partai Hanura di } \\
\text { Sangihe. Menurutnya, Partai } \\
\text { Hanura Sangihe memiliki prospek } \\
\text { yang positif sehingga berpeluang } \\
\text { meraih satu Fraksi di DPDR } \\
\text { Kabupaten Sangihe. } \\
\text { First Fascinating Political } \\
\text { Phenomenon in Indonesia: } \\
\text { Hanura Party trust the disable } \\
\text { figure to lead the structural } \\
\text { party in the district of Sangihe. }\end{array}$ \\
\hline
\end{tabular}

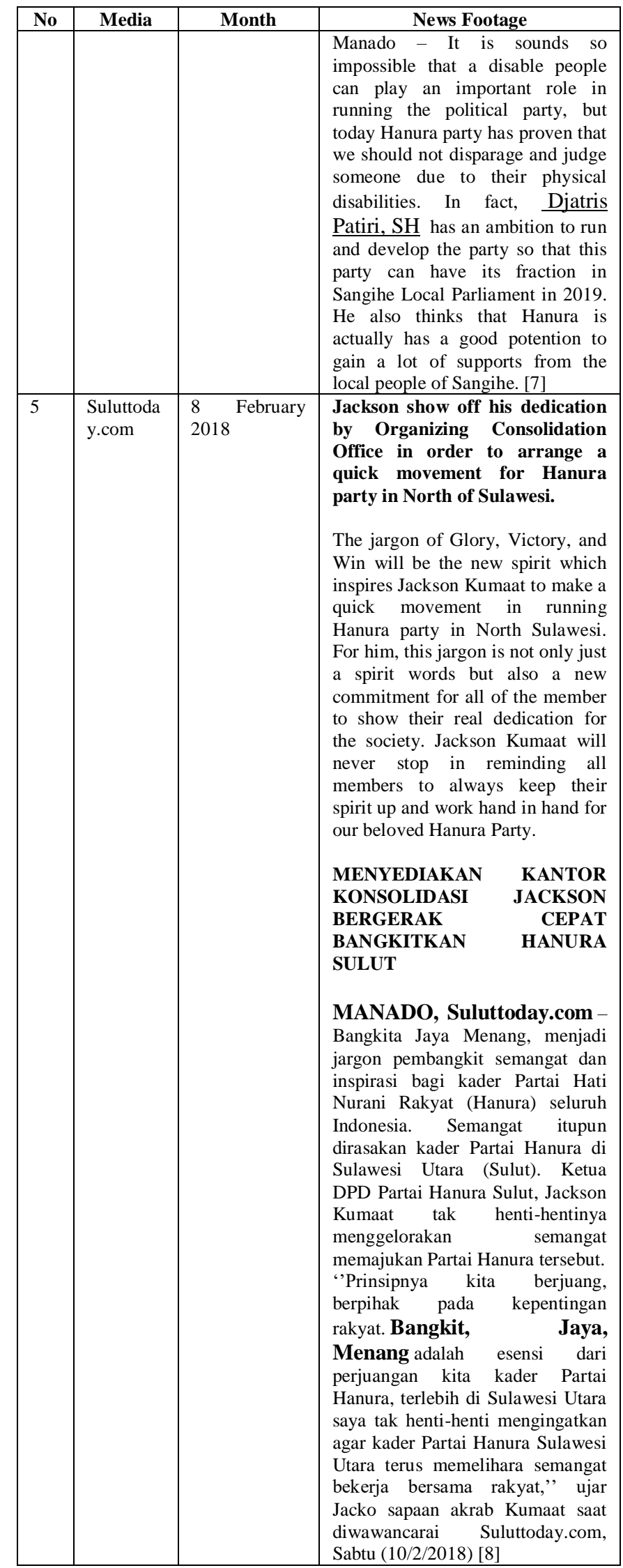




\begin{tabular}{|c|c|c|c|}
\hline No & Media & Month & News Footage \\
\hline 6 & $\begin{array}{l}\text { Suluttoda } \\
\text { y.com }\end{array}$ & $\begin{array}{l}10 \text { February } \\
2018\end{array}$ & $\begin{array}{l}\text { The Strict Jackson: Hanura will } \\
\text { take over back the member card } \\
\text { for those who fight against the } \\
\text { party. } \\
\text { MANADO, Suluttoday.com- } \\
\text { Jackson Kumaat wants to be the } \\
\text { strict Leader in Hanura Party. The } \\
\text { strong commitment in running the } \\
\text { political party in maintaining the } \\
\text { democracy internally will be the } \\
\text { moral value for Jackson Kumaat. } \\
\text { Based on the Internal plenary } \\
\text { session of Hanura held on } \\
\text { Thursday , 8-2-2018, Jackson } \\
\text { Kumaat has announced to all } \\
\text { member of Hanura Party that he } \\
\text { will take over the Hanura member } \\
\text { card for those who being disloyal, } \\
\text { disobey to the party. } \\
\text { TEGAS JACKSON ;DPD } \\
\text { HANURA TARIK KTA } \\
\text { KADER BERMASALAH } \\
\text { Pleno Menjalankan keputusan } \\
\text { kolektif dan demokratis } \\
\text { merupakan prinsip yang selalu } \\
\text { melekat pada sosok Jackson } \\
\text { Kumaat, Ketua DPD Partai Hanura } \\
\text { Sulawesi Utara (Sulut). Kamis } \\
\text { (8/2/2018) berdasarkan hasil rapat } \\
\text { pleno DPD Partai Hanura Sulut, } \\
\text { Jackson menegaskan soal sanksi } \\
\text { tegas yang akan ditindaklanjutinya. } \\
\text { "Secara sah hasil pleno DPD Partai } \\
\text { Hanura Sulawesi Utara } \\
\text { memutuskan adanya penarikan } \\
\text { Kartu Tanda Anggota (KTA) dari } \\
\text { kader yang yang melakukan } \\
\text { pembangkangan dan dianggap } \\
\text { berlawanan dengan kebijakan } \\
\text { partai. Hal itu, berarti menandakan } \\
\text { bahwa kader tersebut dipecat," ujar } \\
\text { Jackson. [9] }\end{array}$ \\
\hline
\end{tabular}

Based on the analysis of those three online medias, we can notice that the agenda setting from those medias focus on the certain politician from the certain political party. There are many news published on portal Manado online post tends to be focus on the figure of Olly Dondokambey and Tety Paruntu. This agenda setting brings some clues to the political contestation for the Mayor Election of Minahasa in 2018, where there will be two different political parties supporting the same candidate voters. It refers to the contestation of elections of minahasa districts in 2018, of which two parties bearers of these two figures carry the same pair of candidates

On the other side, when we read some of the news about Golkar both from the level of district and the level of the province. It clearly shows that the agenda setting from this media always shows its political tension to the certain politician that is Tety Paruntu from Golkar.

Based on the Henri Subiakto's statements, the media ideally has to provide variety information's needed by the people so that the people can think, analyze, and finally create their own opinions and make their own decision in every aspect of life included political issues [10].

The content of the news that has been published by those online media tend to be focus on the personal figure of the politician rather than the ideology of the political party as the organization where the politicians from. The title of the news tends to directly mention the personal name of the politician rather than the public or the political position is being carried by the politician itself. For example the online medias often write Tetty Paruntu instead of the Mayor of Minahasa, Olly Dondokambey instead of the Governor of North Sulawesi and Ivansa instead of the vice of Minahasa Mayor. Besides that, we also know some political jargons using the initial of the politician's personal name such us OD (Olly Dondokambey), CEP (Christina Eugenia Paruntu), CNR (Careig N. Runtu), and so on. Those jargons become the trend in every single news in order to increase the popularity of each candidate in North Sulawesi. In this case we can recognize that the news in North Sulawesi tend to be very focus on the popularity of the personal name rather than the social role of the politician. The people seem to forget that important thing of being the politician is not the name, but the work, gait and the achievements for the society.

While the news are published in menadosatunews.com and sulut today tends to be more focus on the certain political party that is Hanura party with their political elites. We can see the partiality of those medias to the certain political party as the news about Hanura Party and its elites become the most frequently published in those two online medias for two months. Another example is that the first front page of those medias are full of the personal name of Jackson Kumaat from Hanura Party. When it comes to the agenda setting from those medias, it clearly tells us that they lead their news for the political interest for certain candidates and political party. Of course the media has already lost its independence and balance for political purposes but unfortunately it seems normal for the people in North Sulawesi.

\section{CONCLUSION}

We can conclude that majority of the news in online medias in North Sulawesi are politically affected by certain politicians and political parties. In this case, the politician often uses the online media as a tool to increase their popularity in order to win the election that will be held in 2018 and 2019. Unfortunately they prefer to promote their personal name rather than their work or gait to the society

\section{REFERENCES}

[1] E. Santoso, The Theory of Communication.Yogyakarta: Graha Ilmu, 2010 .

[2] W.J. Severin and J. W. Tankard, The Theory of Communication: History, Practical Method in Mass Media, $5^{\text {th }}$ ed. Jakarta: Kencana, 2001.

[3] A. Sobur, Media Text Analysis. Bandung : Rosdakarya, 2006.

[4] http://manadopostonline.com/read/2017/12/15/Pendukung-Ivansa-CNRKian-Meluas/28443 
[5] http://manadopostonline.com/read/2017/12/05/Olly-Tetty-AduKuat $/ 28187$

[6] http://www.manadosatunews.com/2018/01/stevy-suawa-pimpin-hanurakota-manado.htm

[7] http://www.manadosatunews.com/2018/02/pertama-di-indonesia-partaihanura.htm
[8] http://www.suluttoday.com/2018/02/10/menyediakan-kantorkonsolidasi-jackson-bergerak-cepat-bangkitkan-partai-hanura-sulut/

[9] http://www.suluttoday.com/2018/02/08/tegas-jackson-dpd-partaihanura-sulut-tarik-kta-kader-bermasalah/

[10] H. Subiakto and R. Ida, Political Communication Komunika, Media and Democracy. Jakarta: Kencana, 2012. 